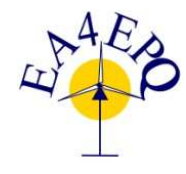

International Conference on Renewable Energies and Power Quality (ICREPQ'16) Madrid (Spain), $4^{\text {th }}$ to $6^{\text {th }}$ May, 2016

Renewable Energy and Pourer Qualily. Fournal (RE\&PQJ)

ISSN 2172-038 X, No.14 May 2016

\title{
The Brazilian automotive market: challenges for the growth of electric and hybrid vehicles
}

\author{
Nilcéia Cristina dos Santos ${ }^{1}$, Reinaldo Gomes da Silva ${ }^{2}$, Maria Helena Bernardo Myczkowski ${ }^{3}$ \\ ${ }^{1}$ College of Technology of Piracicaba "Deputy Roque Trevisan" (FATEC-Piracicaba) \\ CEETPS, State Center of Technological Education Paula Souza \\ Av. Diácono Jair de Oliveira, S/N, Piracicaba/SP (Brazil) \\ Phone number: +55 19 99614-1327 or +55 19 3411-2454 - E-mail: nilceia_santoss@yahoo.com.br, \\ ${ }^{2}$ School of Engineering of Piracicaba (EEP) \\ FUMEP, Municipal Foundation of Piracicaba \\ Av. Monsenhor Martinho Salgot, 560, Piracicaba/SP (Brazil) \\ ${ }^{2}$ College of Technology of Piracicaba "Deputy Roque Trevisan" (FATEC-Piracicaba) \\ CEETPS, State Center of Technological Education Paula Souza \\ Phone number: +55 19 99602-1218 - E-mail: reinaldorgda@gmail.com \\ ${ }^{3}$ College of Technology of Piracicaba "Deputy Roque Trevisan" (FATEC-Piracicaba) \\ CEETPS, State Center of Technological Education Paula Souza \\ Av. Diácono Jair de Oliveira, S/N, Piracicaba/SP (Brazil) \\ Phone number: +55 19 99614-1327 or +55 19 3411-2454 - E-mail: mariahelenabernardo@ @otmail.com
}

\begin{abstract}
The auto industry and related activities are responsible for a billion dollar financial movement worldwide and are not free from pressure often imposed by some sectors of society. Among these pressures there is the concern with the consumption of fossil fuels, which have a significant impact on the quality of the environment (air pollution, climate change, oil spills, and the generation of toxic waste) due to the production of these fuels. In Brazil, facing concerns about the emission of polluting gases, there have arisen several ways to combat this environmental pollution, such as the implementation of public policies aimed at increasing the efficiency of vehicles and diversifying the use of alternatives to fossil fuels (ethanol and biodiesel), and the use of vehicles with smaller internal combustion engines (which are lighter and more economical in terms of fuel consumption and facilitate the recovery of braking energy, formerly dissipated in the form of heat). However, initiatives are still rare in Brazil that aim at the spread of electric and hybrid vehicles, probably due to reasons such as taxation and incentive policies which do not stimulate the quantity of these vehicles in circulation.
\end{abstract}

KEYWORDS: electric vehicles, automotive market, challenges.

\section{INTRODUCTION}

More and more the issue of vehicles is discussed in relation to the preservation of the environment, one reason for this being the reduction of emissions of carbon dioxide $\left(\mathrm{CO}^{2)}\right.$. In recent years, there has been increasing concern about climate change, with studies indicating that the energy balance has suffered interference through an increase in the emission of greenhouse gases (GHG) and solar radiation. This increase is due to the increased use of fossil fuels that elevate the level of carbon dioxide $\left(\mathrm{CO}^{2}\right)$, as well as to increased methane $\left(\mathrm{CH}^{4}\right)$ and nitrous oxide $\left(\mathrm{N}^{2} \mathrm{O}\right)$ emissions generated mostly by transport, agriculture, and livestock (GONÇALVES, 2012).

Changes in the ecosystem have resulted in global warming, which triggers other problems such as reduction of polar ice caps, increased level of the oceans, increased greenhouse effect, and other environmental distortions such as intense drought and torrential rains. It is thus necessary to disseminate policies aimed at improving energy efficiency and the emissions of gases that contribute to global warming (IPCC, 2007).

The burning of fuels for mobile sources exacerbates the problem of air pollution in almost every major city and represents a serious environmental problem, especially when it comes to developing countries. This pollution is caused by different factors, but motor vehicles are among those that contribute the most to aggravating the problem, because they generate pollution and contaminate the environment. Currently, cars are responsible for more than $70 \%$ of the pollution generated in big cities such as Rio de Janeiro, São Paulo, Los Angeles, and Mexico City, among others (MAYER, 1999).

In countries such as France, Germany, Japan, and the United States, for example, there are tax incentive policies and subsidies for electric and hybrid vehicles (VEHs). Without government support through policies of encouragement for research, production, and trade, and 
without public investment in specific infrastructure demanded by users of VEHs, it is not likely that there will be more of these vehicles circulating through the streets.

In Brazil, there are public policies that aim to increase the efficiency of vehicles, both new and used, and to diversify the energy matrix by the use of alternatives to fossil fuels (ethanol and biodiesel). The automotive industry is also involved in the innovation of technologies, developing electric powered and hybrid vehicles which use both electricity with another type of fuel. The vehicles are all partly powered by fuel cells (hydrogen) or batteries (lead or lithium) (RIBERIO and REAL, 2006; RIBEIRO and ABREU, 2008; SILVA, 2011). VEHs, despite being a technologically feasible alternative, often encountered issues such as price and limited autonomy.

To get an idea of the situation in quantitative terms, according to data from the National Association of Automotive Vehicle Manufacturers (ANFAVEA), 855 electric and hybrid vehicles were licensed in Brazil during 2014, as opposed to about 3.14 million light vehicles that use gasoline, ethanol, or natural gas (NGV) as fuel. This represents a share of participation of electric and hybrid vehicles in the Brazilian fleet of about $0.027 \%$, almost double that of the $0.014 \%$ registered in 2013 (ANFAVEA, 2015b).

Within this context, this study aims to analyze the general measures adopted in Brazil to make $\mathrm{VEH}$ vehicles more affordable. The methodology adopted consists of exploratory bibliographical research, effected through books, articles, and theses dealing with the Brazilian automobile market, electric vehicles, and environmental pollution.

The economic, technological, socio-cultural, and environmental transformations which society has undergone seem to indicate a change in the role of vehicles, which are considered culpable with regard to the emission of carbon dioxide (CO2) and the resulting environmental and economic impacts.

\section{REVIEW OF THE LITERATURE}

This literature review seeks to expound some concepts and information that will facilitate understanding of the challenges to the integration and dissemination of electric and hybrid vehicles in Brazil.

\subsection{VEHs in the Brazilian automobile market}

The Brazilian auto industry is among the largest producers of vehicles in the world. Automobile manufacturers in the country are responsible for the production of cars, light commercial vehicles, trucks, and buses. Most of these companies manufacture more than one product category, with the exception of Honda, Hyundai, and Toyota, which manufacture only cars, DAF Trucks, which produces only trucks, and Mahindra and Mitsubishi, which produce only light commercial vehicles (ANFAVEA, 2015b).

In relation to the size of the world automobile fleet, the United States occupies the first position, followed by China in second, and Japan in third place. Brazil appears in eighth place among the countries with the largest auto fleets in the world, with 49,367,978 units (ANFAVEA, 2015a; DENATRAN, 2015). This puts Brazil in a prominent position among the nations with the largest automobile fleets, regardless of size of population, level of economic and technological development, and the existence of automotive vehicles producers in the national territory.

As regards the situation of Latin America, the production and marketing of automotive vehicles has grown exponentially in recent years. In 2014, Brazil sold 3.14 million units of domestic vehicles, which represents more than $43.5 \%$ of all automotive vehicles existing in Latin America (Argentina, Bolivia, Chile, Colombia, Ecuador, Paraguay, Peru, Uruguay, Venezuela, and Mexico) (ANFAVEA, 2015a).

In Brazil in 2014, cars represented $78.37 \%$ of the automotive market, the rest being distributed as follows: $15.06 \%$ light vehicles, $5.03 \%$ trucks, and 1,53\% buses (ANFAVEA, 2015a).

With respect to fuels used by various types of vehicles in Brazil, the dominant matrix is fossil fuel. Different from most countries that use this type of energy source, in the wake of the first oil crisis in 1973 Brazil developed ethanol fuel from the alcohol derived from sugar cane. This model was later improved, and currently biodiesel is also used as an alternative to fossil diesel. Since the mid1990s, the Flex engine, which can use both ethanol and gasoline, has been produced in Brazil. This fact is important from the point of view of pollution generated by $\mathrm{CO} 2$ emissions, because the fleet of Flex cars has increased in the past 20 years, contributing to the reduction of polluting gases in the atmosphere.

One of the arguments of supporters of ethanolpowered cars is that, considering the whole process of ethanol production, they are less polluting than hybrid or electric vehicles (BRAVO, MEIRELES and GIALLONARDO, 2014). With regard to Brazil, the energy matrix used in the national fleet of diverse vehicles has contributed to the reduction of the emission of pollutants. The challenge, as can be seen in Table 1, is to replace the use of diesel fuel as an energy source in trucks, buses, and light commercial vehicles, all of which emit polluting gases.

Table 1 - Licensing of vehicles in fuel categories, 2014

\begin{tabular}{c|c|c|c|c|c}
\hline Vehicles & $\begin{array}{c}\text { Gasoline } \\
\text { (Units) }\end{array}$ & $\begin{array}{c}\text { Ethanol } \\
\text { (Units) }\end{array}$ & $\begin{array}{c}\text { Flex fuel } \\
\text { (Units) }\end{array}$ & $\begin{array}{c}\text { Electric } \\
\text { (Units) }\end{array}$ & $\begin{array}{c}\text { Diesel } \\
\text { (Units) }\end{array}$ \\
\hline Cars & 180,561 & 10 & $2,588,367$ & 842 & 24,907 \\
\hline Light Com. & 4,280 & 4 & 352,127 & 13 & 182,368 \\
\hline Trucks & 0 & 0 & 0 & 0 & 137,059 \\
\hline Buses & 0 & 0 & 0 & 0 & 27,474 \\
\hline Total & $\mathbf{1 8 4 , 8 4 1}$ & $\mathbf{1 4}$ & $\mathbf{2 , 9 4 0 , 4 9 4}$ & $\mathbf{8 5 5}$ & $\mathbf{3 7 1 , 8 0 8}$ \\
\hline
\end{tabular}

Source: ANFAVEA (2015a)

From Table 1 it is possible to notice that $84.06 \%$ of the automobile fleet is powered by Flex engines (gas/ethanol), $10.63 \%$ by diesel, $5.28 \%$ by gasoline only, and $0.02 \%$ by electric motors, the latter coming into use only in 2012 (ANFAVEA, 2015a).

In the case of buses and trucks, $100 \%$ of Brazilian production is with diesel engines. In the case of buses, between the period of 1959 to 1981 only gasoline engines were used, and between 1981 to 1984 there also existed 
the option of the ethanol engine. In relation to trucks, between the years 1957 to 2000 gasoline engines were available, and between 1979 to 1995 there existed the option of the ethanol engine (ANFAVEA, 2015a).

ANFAVEA has presented to the Brazilian Federal Government a proposal for the creation of a program that encourages the development of new propulsion technologies for motor cars, light commercial vehicles, and heavy vehicles. This was a set of measures, with gradual steps of implementation, with the objective making commercially viable the adoption of new propulsion technologies in the Brazilian market and enabling local production. The scenario is favorable because there is an interest on the part of society in models equipped with new engines. In 2014, for example, 855 electric vehicles were licensed, as opposed to 491 in 2013, an increase of 74\% (ANFAVEA, 2015a).

Although Brazil is the seventh largest consumer of electricity in the world, the country is in a favorable situation with regard to its energy matrix, since much of the energy consumed in the country is from renewable sources (hydropower, wood, sugarcane, and other sources). In the rest of the world, $86 \%$ of the primary energy matrix is not renewable (oil, natural gas, steam coal, metallurgical coal, uranium), and there is a great dependence on oil (ROCHA, 2013).

With a diversified energy matrix, the national fleet of vehicles uses few electrics cars as an alternative to fossil fuels (SANTOS, FRANCISCHETTI e SILVA, 2013).

ANFAVEA's proposal suggested six classifications of propulsion technologies for automobiles and light commercial vehicles: mild hybrid, full hybrid, plug-in hybrid, electric with extended autonomy, full electric, and fuel cell. In the heavy vehicles segment, which includes trucks and buses, there are eight classifications involving all fuels known today: biodiesel, biogas, ethanol, diesel, electricity, hydrogen, diesel, and gas (ANFAVEA, 2015a).

In Brazil, the Federal Government designed a national program for the renewal of the fleet of trucks. This project has been developed with the participation of the main actors linked to the transport of cargo: National Confederation of Transport (CNT), National Federation of Motor Vehicle Distribution (FENABRAVE), Brazil Steel Institute, National Institute of Scrap Iron and Steel (INESFA), National Association of Freight Transport and Logistics (NTC), Interstate Syndicate of the Railway and Roadway Materials and Equipment Industry (SIMEFRE), Syndicate of Enterprises of Scrap Iron and Steel (SINDINESFA), National Syndicate of the Automotive Vehicle Components Industry (SINDIPEÇAS), ABC Metal Workers Union (SMABC), National Association of Automotive Vehicle Manufacturers (ANFAVEA). The initial focus of the project is the modernization of the fleet of trucks, with a direct impact on mobility, reducing congestion caused by accidents or mechanical failures, and on the reduction of accidents. In 2012 alone, accidents generated costs of US\$ 1.2 billion to the National Social Security Institute (INSS) and the Unified Health Service (SUS) (ANFAVEA, 2014).

The Brazilian Government intends to deploy a program to replace old trucks are that responsible for the major part of the emission of pollutants into the atmosphere. This program provides for the replacement of approximately 30,000 units per year over ten years, beginning with the adoption of the measures. The vehicles taken out of circulation will be destined, through recycling processes, for the reuse or disposal of components such as steel, iron, and liquid waste.

The withdrawal from service of older vehicles will impact directly on the quality of air. For example, a truck of thirty years old or more, compared to a new model, emits $87 \%$ more carbon, $81 \%$ more hydrocarbons, $86 \%$ more nitrous oxide, and $95 \%$ particulate materials. The vehicle industry will thus also be contributing to the national policy on climate change. New models, that fall within the P7 emissions standard of PROCONVE (see below), consume approximately $10 \%$ less diesel than vehicles with more than thirty years of age. That means less importing of fuel and a savings of about US\$ 1.25 billion over ten years (ANFAVEA, 2014).

According to studies by the Experimental Atmospheric Pollution Laboratory of the Medical School of the University of São Paulo, the pollution generated by vehicles is associated with 200 diseases and 4000 deaths per year in the city of São Paulo alone (HARARI and CRISTI, 2012). The annual cost for the treatment of diseases is approximately US\$ 400 million (MARTINS, 2001)

In the light of this fact, on May 6, 1986, through resolution number 18, the National Environmental Council (CONAMA) created the Program for the Control of Air Pollution by Motor Vehicles (PROCONVE), coordinated by IBAMA. This program defined the emission limits for light vehicles, in order to contribute to the air quality standards established by the National Air Quality Program (PRONAR). According to IBAMA (2012), light vehicles are those designed to transport up to twelve passengers or the equivalent thereof for the transport of cargo (CONAMA. 2012).

To ensure that this requirement be accomplished, IBAMA prohibits the marketing of non-approved vehicles. It is the responsibility of PROCONVE to deal with prototype certification and approval of engines (or their collection if they are in non-compliance with regulations) (IBAMA, 2012). PROCONVE only deals with new vehicles. Older vehicles follow the requirements in effect at the time of their manufacture, and thus end up polluting more.

PROCONVE was divided into stages so that companies had time to adjust to the new emission limits. Phase L-1 (1988), for light vehicles, consisted in eliminating the most polluting vehicles and improving production (SCHOLL, 2009). In Phase L-2 (1992), in order to achieve the levels required at this stage, vehicles had to adopt new technologies such as electronic fuel injection and catalytic converters. As ethanol is used along with gasoline, use of technology was necessary to allow for the suitability of catalytic converters and electronic injection (SCHOLL, 2009). Phase L-3 (1997) was responsible for adding oxygen sensors to engines (SCHOLL, 2009). Phases L-4 (2003), L-5 (2009), and L-6 (2012) are characterized by level reduction, not requiring manufacturers to install equipment or items such as engines (SCHOLL 2009). 


\subsection{Challenges to the integration and dissemination of VEHs in Brazil}

In the current Brazilian fleet, fuel cars prevail (either Flex or gasoline vehicles). The introduction of VEHs, especially purely electric vehicles, requires investment in technology and infrastructure and is highly dependent on government incentives.

The use of VEHs brings with it some benefits, which in the view of Bravo, Meirelles and Giallonardo (2014) are the following:

a) With an energy matrix that uses renewable and nonrenewable sources, it is not necessary to use only energy produced by hydroelectric stations;

b) The possibility of creating and using smart grid networks. These are intelligent networks for the distribution of electricity with real-time communication between consumers and producers, allowing in this way the monitoring of energy consumption rates in the network;

c) A favorable trade balance with regard to petroleum. At present the United States is the biggest consumer of petroleum and oil products in the world, surpassing 20 million barrels per day $(21.7 \%$ of world consumption), and only $33 \%$ of this consumption is produced within the country;

d) Mitigation of pollution, reducing the emission of harmful gases.

For Bravo, Meirelles and Giallonardo (2014), if these advantages are to become a reality, government efforts will be necessary to encourage automakers and awaken the interest of consumers, in addition to overcoming the other barriers that are discussed below.

\section{a) Public policies:}

Worldwide, government incentive actions for VEHs occur in five ways: providing exemptions or tax discounts, bonuses or subsidies to buyers of VEHs, adoption of restrictions on the use of conventional vehicles, assistance in research and development, and financial contributions to the development of infrastructure. However, at this moment, little has been done about these public policies in Brazil. For example, there is an exemption from the IPVA (Property Tax on Motor Vehicles) for electric vehicles in seven Brazilian states (Ceará, Maranhão, Pernambuco, Piauí, Rio Grande do Norte, Rio Grande do Sul, and Sergipe) and a differentiated rate in three other states (Mato Grosso do Sul, Rio de Janeiro, and São Paulo).

\section{b) Absence of infrastructure:}

There is a need for major investment in infrastructure, as in Brazil there are only fifty refill points throughout the national territory, in contrast to the nearly 5000 installed in Japan. Another factor to consider are the long distances traveled on Brazilian roads, which would require an amount of recharge points far superior that that of Europe. Another aggravating factor is the inadequate public transport system (buses, subways, bike paths, etc.), which leads Brazilians to opt increasingly for individual transport. Stimulating the production and sale of VEHs will require the formation of skilled labor to work from concept to maintenance of these vehicles, because Brazil does not even produce lithium batteries.

\section{c) Competition from ethanol:}

In Brazil, there is a fear in the sugar ethanol sector about a suspension of investment in ethanol, layoffs in large amounts, and the entry of foreign capital which would weaken the national groups. The big automakers in Brazil have the desire to keep ethanol as the sole source of renewable energy used in the transport sector, as a way to preventing the opening of the market for electric and hybrid vehicles and making possible the arrival of competitors in Brazil.

\section{d) Taxation:}

In Brazil it is necessary to expand the reduction or exemption of taxes on a large scale, as already occurs in Europe. One of the measures is to create a specific tax category for VHEs, as currently VHEs are classified along with other vehicles, generating a greater tax burden. For example, they pay a 25\% IPI (Industrialized Product Tax), which is the maximum percentage of this tax, in addition to paying other taxes. The GRUVE (Study Group on the Electric Vehicle) suggests a tax that is proportional to energy consumption $(\mathrm{MJ} / \mathrm{km})$ and the emission of nonrenewable carbon dioxide $(\mathrm{gCO} 2 / \mathrm{km})$, so that the more efficient and less polluting cars would pay less taxes.

To illustrate the situation, in Brazil the taxes on the price of cars are larger than those of other countries (Figure 1):

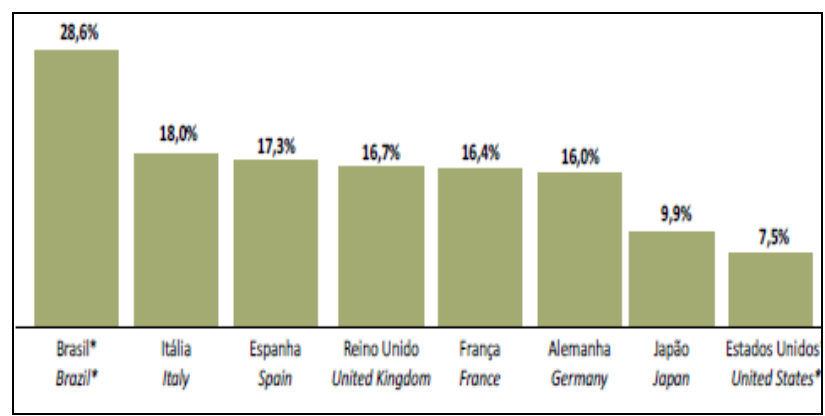

Figure 1 - Tax burden on cars in selected countries - share of consumer price, 2014

Source: (ANFAVEIA, 2015a, p. 52)

Another barrier that can occur in the case of imported VEHs are the various additional costs such as the import taxes, port taxes, customs fees, annual fees from public agencies, and insurance.

\section{FINAL CONSIDERATIONS}

We began this article by discussing the Brazilian automobile market, identifying companies located in Brazil and the types of vehicles produced and providing to data on this sector in the country and its representation in the world market of motor vehicles. 
In Brazil, cars represent $78.37 \%$ of the automotive market, the rest being spread between light vehicles with $15.06 \%$, trucks with $5.03 \%$, and buses with $1.53 \%$. From 2003-2013, the production of vehicles increased significantly, in particular the commercial segment, which grew $359 \%$ (ANFAVEA, 2015a).

In relation to the fuel used by the various types of vehicles in Brazil, the dominant matrix is fossil fuel, unlike in most countries where other energy sources are used. It is in this context that the electric car is emerging as an alternative to using fossil fuels. In Brazil the use of electric cars represents only $0.02 \%$ of total vehicles produced. With a diversified energy matrix, the national fleet of vehicles makes little use of electric cars as an alternative to fossil fuels (SANTOS, FRANCISCHETTI e SILVA, 2013).

The technology and the production of biofuels have a long history in Brazil, and the country has the expertise necessary for the continuation of biofuels development and in particular for the production of ethanol fuel, which may help with minimizing $\mathrm{CO} 2$ pollution and negative environmental impacts.

In 1986, the National Environmental Council (CONAMA) created the Program for the Control of Air Pollution by Motor Vehicles (PROCONVE), whose primary purpose was to set emission limits for light vehicles, so as to meet the air quality standards established by PRONAR (National Air Quality Program). PROCONVE was implemented in phases starting in 1988, and was foreseen as ending in 2015. The measure was effective because the rates of emission of pollutants were reduced in each phase.

As the Brazilian fleet has not yet reached a level of saturation and is predicted to grow by $120 \%$ by 2030 in relation to the current fleet, the incentive to use VEHs in Brazil (to the detriment of conventional cars) would bring strategic and effective environmental benefits more rapidly than in countries like the US, where the number of cars in the fleet has reached a level of stagnation and the replacement of the fleet can be a long and time-consuming process that can take decades.

This study is not conclusive, and there is a need for collecting more information about proposals to that aim to reduce the levels of pollutants, for analyzing the incentives for the use of electric and hybrid vehicles, and for examining the barriers of entry for this type of product.

\section{REFERENCES}

[1] ANFAVEA. Brazilian Automotive Industry Yearbook - 2015. 2015a.

$<$ http://www.anfavea.com.br/anuario.html $>$. 26/10/2014.

[2] ANFAVEA. Brazil Automotive Guide 2014: guide to the Brazilian automotive industry sector. 2014. http://www.autodata.com.br/pages.php?recid=19508>. 27/10/2014.

[3] ANFAVEA. Carta da ANFAVEA Outubro 2015. http://www.anfavea.com.br/cartas/carta353.pdf>. 18/10/2015.

[4] BRAVO, Diego Moreno; MEIRELLES, Pablo Siqueira; GIALLONARDO, Walace. Análise dos desafios para a difusão dos veículos elétricos e híbridos no Brasil. Blucher Engineering Proceedings. Ago. 2014, n. 2, v. 1, p. 1-22.

[5] CONAMA - Conselho Nacional do Meio Ambiente. Resoluções do CONAMA: publicadas entre setembro de 1984 e janeiro de 2012. Ministério do Meio Ambiente. Brasília: MMA, 2012.

[6] HARARI, Isabel; CRISTI, André. 2012. Pobres são os mais atingidos pela poluição urbana.

<http://cartamaior.com.br/?/Editoria/Politica/Pobressao-os-mais-atingidos-pela-poluicao-urbana-dizmedico-da-USP/4/25595>. 17/01/2015.

[7] IPCC. Climate Change. 2007. Synthesis Report. Contribution Of Working Groups I, II and III to the Fourth Assessment Report of the Intergovernmental Panel on Climate Change [Core Writing Team, Pachauri, R.K. and Reisinger, A. (eds.). IPCC, Geneva Switzerland, $104 \mathrm{p}$.

[8] MAYER, Helmut. 1999. Air pollution in cities. Atmospheric Environment. v.33, n. 24-24, p. 4029 4037.

[9] RIBEIRO, Suzana K.; ABREU, Adrianna. A. (2008). Brazilian transport initiatives with GHG reductions as a co-benefit. Climate Policy. v.8, n.2, p. 220-240.

[10] ROCHA, Luiz. Carro Elétrico - Desafios para sua Inserção no Mercado Brasileiro de Automóveis. Dissertação para obtenção do título de Especialista em Gestão e Tecnologias Ambientais. Escola Politécnica da USP, 2013.

[11] SANTOS, Nilcéia Cristina dos; FRANCISCHETTI, Carlos Eduardo; SILVA, Reinaldo Gomes da. Analysis of electric vehicles: a Brazilian reality and its consequences for the environment. Renewable Energy and Power Quality Journal (RE\&PQJ), n. 12, April 2014, p. 1-6;

[12] SILVA, Elenice Rachid. Análise do crescimento da motorização no Brasil e seus impactos na mobilidade urbana. 2011. 142p. Dissertation (Mestrado do Programa de Planejamento Energético/COOPE) - Universidade Federal do Rio de Janeiro (UFRJ), Rio de Janeiro. 2011. 